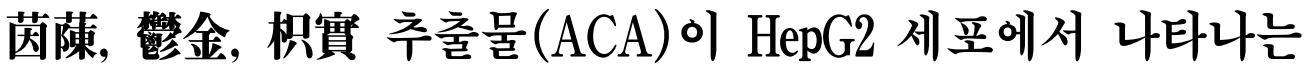 이상지질혈증 관련 인자 발현 및 항산화에 미치는 영향
}

유주영, 조현경, 유호룡, 설인찬, 김윤식

대전대학교 한의과대학 심계내과학교실

\section{The Effects of Artemisiae Iwayomogii Herba, Curcumae Radix, and Aurantii Fructus Immaturus Complex Extract (ACA) on Dyslipidemia-related Factor Expression and Anti-oxidation in HepG2 Cells}

\author{
Ju-young Ryu, Hyun-kyoung Cho, Ho-ryong Yoo, In-chan Seol, Yoon-sik Kim \\ Dept. of Circulatory Internal Medicine, College of Korean Medicine, Dae-Jeon University
}

\begin{abstract}
Objective: To investigate the effect of Artemisiae Iwayomogii Herba, Curcumae Radix, and Aurantii Fructus Immaturus complex extract (ACA) on dyslipidemia-related factor expression and anti-oxidation in HepG2 cells.

Method: After treatment with ACA in the HepG2 cells, DPPH, ABTS radical scavenging activity, ROS production, and glutathione (GSH) production were measured. The free fatty acid, lipid peroxidation (MDA), ACAT1, and HMG-CoA reductase mRNA expression were measured in the HepG2 cells after treatment with ACA.

Results:

1. DPPH, ABTS radical scavenging activity increased in an ACA concentration-dependent manner.

2. ACA significantly decreased ROS production in comparison to the control group.

3. ACA significantly increased glutathione production.

4. ACA significantly decreased free fatty acid and lipid peroxidation (MDA) in the HepG2 cells.

5. ACA decreased the mRNA expression of ACAT1 and $\mathrm{HMG}^{-\mathrm{CoA}}$ reductase.

Conclusion: These results suggest that Artemisiae Iwayomogii Herba, Curcumae Radix, and Aurantii Fructus Immaturus complex extract (ACA) inhibits dyslipidemia-related factor expression and that it is effective in anti-oxidation. A future in vivo experiment with ACA is needed to investigate the effect on anti-dyslipidemia. It is expected that ACA is effective in anti-dyslipidemia and applied to cardiovascular disease, ischemic heart disease, stroke, etc.
\end{abstract}

Key words: Artemisiae Iwayomogii Herba, Curcumae Radix, Aurantii Fructus Immaturus, anti-oxidation, dyslipidemia

\section{I. 서 론}

전 세계적으로 심혈관계질환으로 사망하는 인구

· 투고일: 2017.03.22, 심사일: 2017.06.26, 게재확정일: 2017.06.30

· 교신저자: 김윤식 충남 천안시 서북구 노태산로 4 대전대부속천안한방병원

TEL: 041-521-7536 FAX: 041-521-7007

E-mail: yoonsik@dju.kr

. 이 논문은 2017년도 대전대학 대학원 한의학 석사학위 논문임.
가 연간 1,700 만 명이며, 이는 전체 사망 원인의 $30 \%$ 에 달한다 ${ }^{1}$. 이상지질혈증은 서구화된 식이와 운동부족과 같은 생활습관 등에 따라 증가하는 추 세이며 ${ }^{2}$ 필요 이상으로 혈관 내 많은 지질성분 물 질은 염증인자를 활성화시켜 만성적인 염증 상태 를 유발하고 죽상동맥경화를 유발시키기 때문에 이상지질혈증의 관리 및 치료는 중요하다. 이상지 질혈증의 치료는 식사요법이나 운동요법, 금연 등 
茵蔯, 棍金, 枳實 추출물(ACA)이 HepG2 세포에서 나타나는 이상지질혈증 관련 인자 발현 및 항산화에 미치는 영향

의 생활습관 개선이 먼저 고려되며 정도에 따라서 약물요법이 병행하기도 한달. 그러나 치료 효과와 더불어 소화장애, 간 독성, 근육 독성의 부작용이 나타날 수 있어 이러한 단점을 보완하기 위해서 천연 한약물에서의 연구도 활발하게 이루어지고 있다 ${ }^{3}$.

이상지질혈증의 치료제로 단미약으로는 茵蔯 ${ }^{3}$,

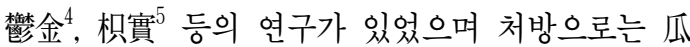
萋枳實湯 ${ }^{6}$, 枸杞子加味方 ${ }^{7}$ 등의 연구가 있었다. 그 리고 약침을 이용한 연구 ${ }^{8}$ 등 다양한 치료제 개발 이 활발히 이루어지고 있다.

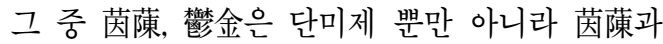
冧金 복합추출물로서도 항고지혈 효능이 밝혀진 바 있으며 ${ }^{9}$ 茵蔯과 穮金 복합추출물에 단미제를 추가하 여 항산화 및 항고지혈 효능을 평가하려는 연구 ${ }^{1011}$ 가 계속되고 있다. 枳實은 단미제로서 triglyceride와 혈청 total cholesterol에 대하여 simvastatin 못지않게 고지혈증 억제 효과를 나타내었고 HDL-cholesterol 상승과 LDL-cholesterol 저하 효과가 있다고 밝혀 져 있다 ${ }^{5}$. 그러나 복합제로서는 아직 효증이 규명 되지 않아 본 실험을 통해 茵蔯, 簏金, 枳實 복합추 출물의 효능을 규명하고자 연구를 진행하게 되었다.

본 연구에서는 항산화 효능을 평가하기 위하여 $\mathrm{DPPH}$ radical 소거능, ABTS radical 소거능을 측 정했으며 세포 내 ROS의 생성량, glutathione의 함 량을 측정했다. 이상지질혈증의 개선 효능 평가를 위하여 세포 내 free fatty acid 함량과 세포 내 lipid peroxidation, cholesterol 관련 인자인 ACAT1 과 $\mathrm{HMG}^{-\mathrm{CoA}}$ reductase $\mathrm{RNA}$ 발현 수준을 측정하 였으며 유의한 결과를 얻었기에 발표하는 바이다.

\section{II. 재료와 방법}

1. 재 료

1) 약 재

본 실험에서 사용한 인진, 울금, 지실 복합물 (Artemisiae Iwayomogii Herba, Curcumae Radix,
Aurantii Fructus Immaturus complex extract 이하. $\mathrm{ACA}$ 로 표기)의 구성 약재들은 (주옴니허브에서 구 입해 사용하였고, 그 내용 및 분량은 다음과 같다 (Table 1).

Table 1. The Prescription of ACA

\begin{tabular}{|c|c|c|}
\hline $\begin{array}{c}\text { Herbal } \\
\text { medicine } \\
\text { name }\end{array}$ & Pharmacognostic name & $\begin{array}{l}\text { Weight } \\
(\mathrm{g})\end{array}$ \\
\hline 茵 蔯 & Artemisiae Iwayomogii Herba & 10 \\
\hline 鬱 金 & Curcumae Radix & 10 \\
\hline \multirow[t]{3}{*}{ 枳 實 } & Aurantii Fructus Immaturus & 10 \\
\hline & Total amount & 30 \\
\hline & Final yield & $14.80 \%$ \\
\hline
\end{tabular}

2. 방 법

1) 시료 추출

$\mathrm{ACA}(30 \mathrm{~g})$ 를 $80 \%$ 주정의 $500 \mathrm{ml}$ 에 넣어 3시간 동안 환류추출을 한 이후 여과액을 rotary vacuum evaporator를 통하여 감압 농축하였다. 농축된 용 액을 freeze dryer를 이용하여 동결 건조를 하여 분 말 $4.439 \mathrm{~g}$ (수율 $14.80 \%$ )을 얻어냈고, 얻어진 분말 은 초저온 냉동고 $\left(-80{ }^{\circ} \mathrm{C}\right)$ 에서 보관했으며 실험에 필요한 농도로 증류수에 희석하여 사용하였다.

2) 중금속 검사

준비된 검액과 표준액, 공시험액을 가지고 유도 결합플라즈마-원자방출분광계(ICP-AES)를 사용하 여 검량선을 작성 후 공시험액으로 보정하여 검액 을 측정하였다.

3) HepG2 세포 배양

HepG2 세포는 1\% antibiotic-antimycotic와 10\% fetal bovine serum(FBS)으로 조성된 D MEM 배지 를 사용하여 $37{ }^{\circ} \mathrm{C}, 5 \% \mathrm{CO} 2$ 조건이 유지되는 세 포배양기에서 배양하였으며, 2-3일 주기로 계대배 양하여 실험을 진행하였다.

4) 항산화 효능평가

(1) $\mathrm{DPPH}$ radical 소거능 측정

$\mathrm{DPPH}$ radical 소거능 측정은 추출물 $\mathrm{ACA}$ 의 최 
종 농도가 $1,10,100,1,00(\mu \mathrm{g} / \mathrm{ml})$, 의 농도로 희석 하였으며, DPPH 용액 $150 \mu \mathrm{l}$ 와 추출물 $\mathrm{ACA}$ 를 각 각 $100 \mu \mathrm{l}$ 을 반응 시켜 흡광도를 측정하였다. 시료 액의 대조군에는 증류수를 넣었으며, DPPH 용액 의 대조군으로써는 에탄올을 넣어 보정값을 얻었 다. DPPH radical 소거율은 아래의 식에 따라 계 산하였다.

$$
\text { 소거율 }(\%)=
$$

(대조군의 흡광도-시료 첨가군의 흡광도 $) \times 100$

(2) ABTS radical 소거능 측정

$\mathrm{ABTS}$ radical 소거능 측정은 $\mathrm{ACA}$ 추출물의 최 종 농도가 $1,10,100,1,000(\mu \mathrm{g} / \mathrm{ml})$, 의 농도로 될 수 있게 희석시켰으며, 희석된 ABTS+용액 $150 \mu \mathrm{l}$ 와 $\mathrm{ACA}$ 추출물을 각각 $5 \mu \mathrm{l}$ 혼합하고, 실온에서 10 분간 반응시킨 후, $732 \mathrm{~nm}$ 에서 흡광도를 측정하 였다. 항산화능은 증류수를 대조군으로 하여 대조 군에 대한 ABTS radical 소거능을 백분율로 나타 내었다.

소거율 $(\%)=$

(대조군의 흡광도-시료 첨가군의 흡광도 $) \times 100$

(3) 세포 내 reactive oxygen species(ROS) 생성 측정

세포 내 ROS를 측정하기 위하여 2', 7'-dichlorofluorescin diacetate (DCF-DA)를 이용하였다. ACA 추출물 1 , $10,100(\mu \mathrm{g} / \mathrm{ml})$ 의 농도로 처리하여 실험이 이루어 졌으며 유세포 분석기를 이용하여 형광강도의 세 기에 따른 변화를 분석하였다.

(4) 세포 내 glutathione(GSH) 함량 측정

세포 내 GSH 함량을 측정하기 위하여 Glutathione assay kit를 이용하여 다음과 같이 측정하였다. ACA 추출물을 각각 $1,10,100(\mu \mathrm{g} / \mathrm{ml})$ 의 농도로 처리하 여 실험이 이루어졌으며 $\mathrm{NADPH}(0.16 \mathrm{mg} / \mathrm{ml})$ 를 $50 \mu 1$ 씩 넣어준 뒤 $412 \mathrm{~nm}$ 파장에서 5 분 동안 1 분 간격으로 흡광도를 측정하였다. GSH 농도를 표준 용액의 정량곡선을 기준으로 계산하였다.
5) 항고지혈 효능평가

(1) 세포 내 Free fatty acid 함량 측정

세포 내 free fatty acid 함량을 Free Fatty Acid Quantitation Kit를 이용하여 측정하였다. ACA 추 출물을 각각 $1,10,100(\mathrm{\mu g} / \mathrm{ml})$ 의 농도로 처리하여 실험이 이루어졌으며 Free fatty acid 함량은 kit에 포함된 palmitic acid 표준용액 ${ }^{12}$ 의 정량곡선을 기 준으로 계산하였다.

(2) 세포 내 Lipid peroxidation(MDA) 측정

세포 내 $\mathrm{MDA}$ 를 측정하기 위하여 lipid peroxidation (MDA) kit를 이용하여 측정하였다. $\mathrm{ACA}$ 추출물 을 각각 $1,10,100(\mu \mathrm{g} / \mathrm{ml})$ 의 농도로 처리하여 실험 이 이루어졌으며 $\mathrm{MDA}$ 농도를 표준용액의 정량곡 선을 기준으로 계산하였다.

(3) Reverse transcription PCR

세포 내 ACAT1, HMG-CoA reductase 발현 수 준을 측정하였다. $\mathrm{ACA}$ 추출물을 각각 $1,10,100$ $(\mu \mathrm{g} / \mathrm{ml})$ 의 농도로 처리하여 실험이 이루어졌으며 시료가 처리된 HepG2 세포에서 total RNA를 추 출한 후 $\mathrm{cDNA}$ 를 합성하고 $\mathrm{PCR}$ 을 수행하여 전기 영동한 후 UV촬영을 통해 결과를 확인하였다.

\section{3. 통계처리}

실험 결과는 SPSS 11.0의 unpaired student's T-test와 ANOVA를 사용하여 통계처리 하였고 $p<0.05, p<0.01$ 및 $p<0.001$ 수준에서 그 유의성을 검 정하였다.

\section{III. 실험 결과}

\section{1. 중금속 검사}

중금속 함량을 측정한 결과, $\mathrm{ACA}$ 는 납, 카드뭄 의 경우 기준치 이하로 검출되었고 비소, 수은의 경우는 검출되지 않았다(Table 2). 


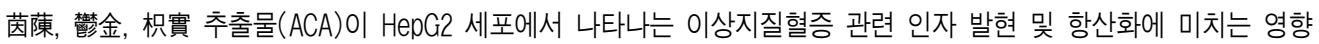

Table 2. Content of $\mathrm{Pb}, \mathrm{As}, \mathrm{Cd}$ and $\mathrm{Hg}$ in $\mathrm{ACA}$ Extract

\begin{tabular}{ccccc}
\hline Primer & $\mathrm{Pb}$ & $\mathrm{As}$ & $\mathrm{Cd}$ & $\mathrm{Hg}$ \\
\hline permissive density $(\mathrm{mg} / \mathrm{kg})$ & 5 & 3 & 0.3 & 0.2 \\
ACA & 0.91 & N.D. & 0.05 & N.D. \\
\hline
\end{tabular}

N.D. : not detected

\section{2. 항산화 효능평가}

1) $\mathrm{DPPH}$ radical 소거능 측정

$\mathrm{ACA}$ 추출물의 $1,10,100,1,000(\mathrm{\mu g} / \mathrm{ml})$ 농도에 서 $\mathrm{DPPH}$ radical 소거능은 각각 $15.20 \pm 1.30 \%$, $17.80 \pm 1.80 \%, 32.20 \pm 1.30 \%, 71.50 \pm 13.60 \%$ 로 나타나 농도 의존적으로 $\mathrm{DPPH}$ radical 소거능 증가가 나 타났다. Ascorbic acid의 DPPH radical 소거능은 0, $1.95,7.81,31.25(\mu \mathrm{g} / \mathrm{ml})$ 농도에서 각각 $0.00 \pm 1.60 \%$, $34.35 \pm 3.23 \%, 49.17 \pm 4.73 \%, 72.91 \pm 10.77 \%$ 로 나타났 다(Fig. 1).

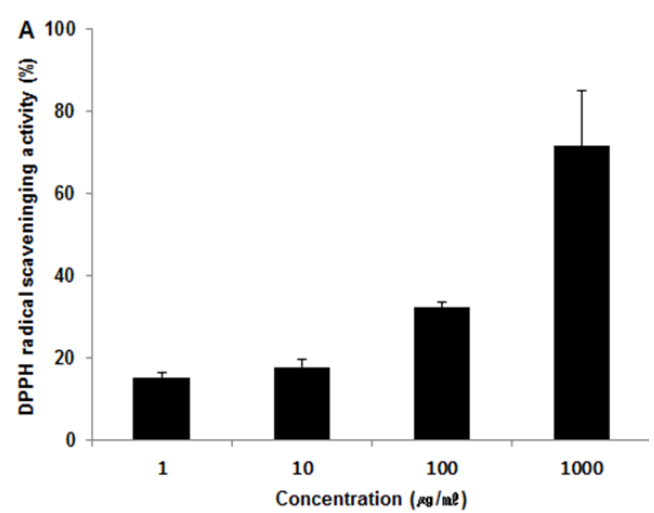

Fig. 1. DPPH radical scavenging activity of ACA extract.

2) ABTS radical 소거능 측정

$\mathrm{ACA}$ 추출물의 $1,10,100,1,000(\mathrm{\mu g} / \mathrm{ml})$ 농도에서 ABTS radical 소거능은 각각 $2.20 \pm 0.80 \%, 5.80 \pm 0.90 \%$, $24.60 \pm 16.10 \%, 94.60 \pm 0.10 \%$ 로 나타나 농도 의존적으 로 ABTS radical 소거능 증가가 나타났다. Ascorbic acid의 ABTS radical 소거능은 $0,1.95,7.81,31.25$ $(\mu \mathrm{g} / \mathrm{ml})$ 농도에서 각각 $0.00 \pm 0.23 \%, 5.28 \pm 0.89 \%$,
$25.83 \pm 1.52 \%, 93.05 \pm 0.60 \%$ 로 나타났다(Fig. 2).

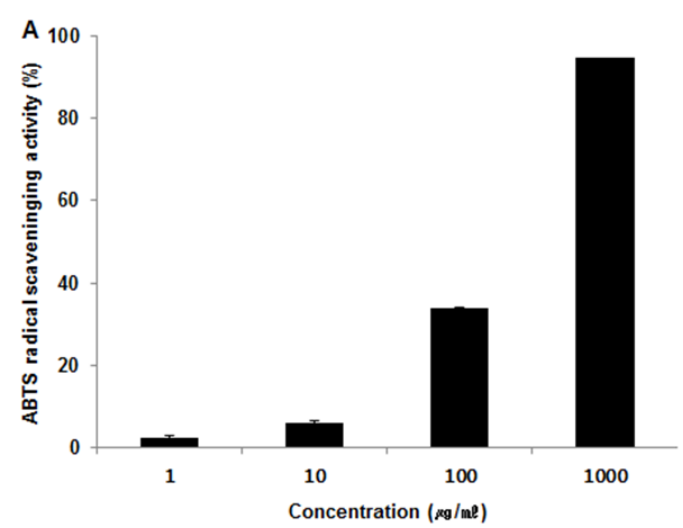

Fig. 2. ABTS radical scavenging activity of ACA extract.

3) 세포 내 ROS 측정

세포 내 ROS를 측정한 결과, 정상군에서 61.26 $\pm 2.51 \%$, 대조군에서 $100.00 \pm 0.14 \%$ 를 나타낸 반면, $\mathrm{ACA}$ 추출물 $1,10,100(\mathrm{\mu g} / \mathrm{ml})$ 농도에서 각각 $22.14 \pm 1.35 \%, \quad 18.36 \pm 1.06 \%, \quad 16.28 \pm 0.97 \%$ 로 나타나 모든 농도에서 유의성 있는(*** : $\mathrm{p}<0.001)$ 감소가 나타났다(Fig. 3).

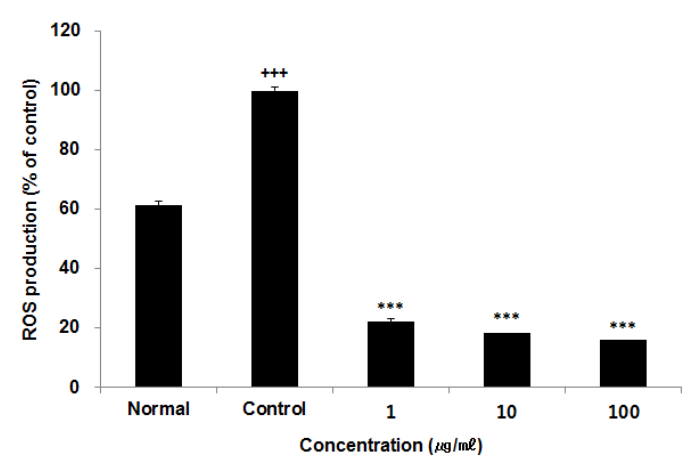

Fig. 3. Effect of ACA extract on ROS production in HepG2 cells.

$+++: p<0.001$ compare to normal, ${ }^{* * *}: p<0.001$ compare to control. Normal : non-treated HepG2 cells, Control : 1 mM H2O2-treated HepG2 cells 
4) 세포 내 GSH 함량 측정

세포 내 GSH 함량을 측정한 결과, 정상군에서 $73.89 \pm 0.32 \mathrm{nmol} / \mathrm{ml}$, 대조군에서 $39.70 \pm 0.85 \mathrm{nmol} / \mathrm{ml}$ 를 나타낸 반면, $\mathrm{ACA}$ 추출물 $1,10,100(\mu \mathrm{g} / \mathrm{ml})$ 농도 에서 각각 $43.70 \pm 2.68 \mathrm{nmol} / \mathrm{ml}, 42.23 \pm 2.11 \mathrm{nmol} / \mathrm{ml}$, $48.39 \pm 1.75 \mathrm{nmol} / \mathrm{ml}$ 로 나타나 $1,10,100(\mu \mathrm{gg} / \mathrm{ml})$ 농 도에서 유의성 있는(*: $\left.\mathrm{p}<0.05,{ }^{* *}: \mathrm{p}<0.01\right)$ 증가가 나타났다(Fig. 4).

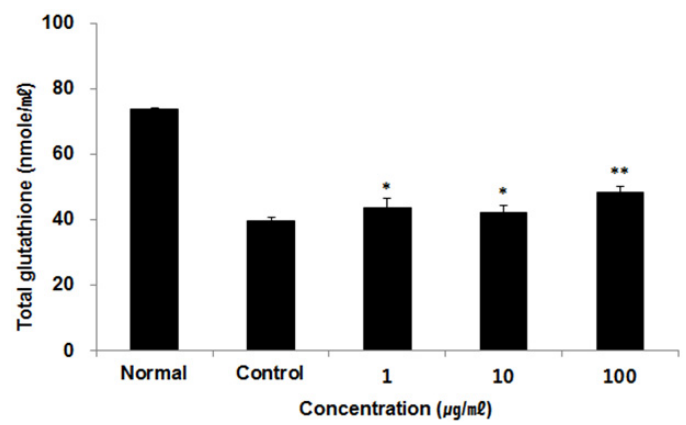

Fig. 4. Effect of ACA extract on total GSH contents in HepG2 cells.

* : $\mathrm{p}<0.05,{ }^{* *}: \mathrm{p}<0.01$ compare to control. Normal : non-treated HepG2 cells, Control : $1 \mathrm{mM}$ H2O2-treated HepG2 cells

\section{3. 항고지혈 효능평가}

1) 세포 내 free fatty acid 함량 측정

세포 내 free fatty acid 함량을 측정한 결과, 정 상군에서 $41.26 \pm 1.32 \mathrm{nmol} / \mathrm{ml}$, 대조군에서 $70.60 \pm$ $2.36 \mathrm{nmol} / \mathrm{ml}$ 를 나타낸 반면, $\mathrm{ACA}$ 추출물 1,10 , $100(\mu \mathrm{g} / \mathrm{ml})$ 농도에서 각각 $61.86 \pm 3.05 \mathrm{nmol} / \mathrm{ml}$, $60.57 \pm 4.52 \mathrm{nmol} / \mathrm{ml}, 56.09 \pm 3.29 \mathrm{nmol} / \mathrm{ml}$ 로 나타나 모든 농도에서 유의성 있는(* : p $<0.05,{ }^{* *}: \mathrm{p}<0.01$, *** : p $<0.001$ ) 감소가 나타났다(Fig. 5).

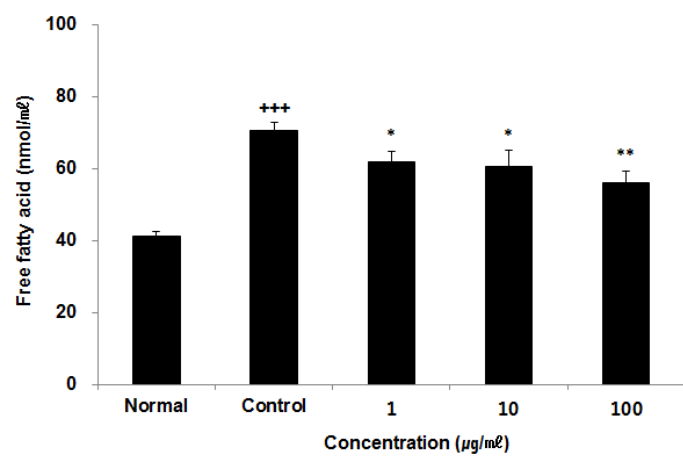

Fig. 5. Effect of ACA extract on free fatty acid contents in HepG2 cells.

$+++: p<0.001$ compare to normal, ${ }^{*}: p<0.05$, ** : p<0.01 compare to control. Normal : non-treated HepG2 cells, Control : $0.5 \mathrm{mM}$ FAs (palmitate; oleic acid, 6:4)-treated HepG2 cells

2) 세포 내 $\mathrm{MDA}$ 측정

세포 내 $\mathrm{MDA}$ 를 측정한 결과, 정상군에서 3.61 $\pm 0.03 \mathrm{nmol} / \mathrm{mg}$, 대조군에서 $4.35 \pm 0.09 \mathrm{nmol} / \mathrm{mg}$ 를 나타낸 반면, $\mathrm{ACA}$ 추출물 $1,10,100(\mu \mathrm{g} / \mathrm{ml})$ 농도 에서 각각 $3.39 \pm 0.17 \mathrm{nmol} / \mathrm{mg}, 2.27 \pm 0.13 \mathrm{nmol} / \mathrm{mg}$, $3.14 \pm 0.25 \mathrm{nmol} / \mathrm{mg}$ 로 나타나 모든 농도에서 유의 성 있는(*** : p<0.001) 감소가 나타났다(Fig. 6).

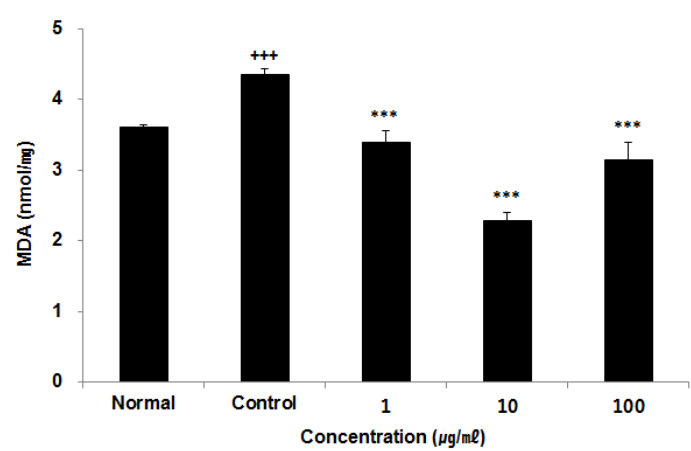

Fig. 6. Effect of ACA extract on MDA in HepG2 cells.

$+++: p<0.001$ compare to normal, $* * *: p<0.001$ compare to control. Normal : non-treated HepG2 cells, Control : 1 mM H2O2-treated HepG2 cells 
3) 세포 내 mRNA 발현 수준 확인

세포 내 $\mathrm{ACAT1}$ 과 $\mathrm{HMG}-\mathrm{CoA}$ reductase mRNA 발현 수준을 확인한 결과, 정상군에 비해 대조군에 서 현저히 증가되어 있었으며, $\mathrm{ACA}$ 추출물 1,10 , $100(\mu \mathrm{g} / \mathrm{ml})$ 농도에서 ACAT1과 HMG-CoA reductase $\mathrm{mRNA}$ 발현량이 감소된 것으로 확인되었다(Fig. 7).

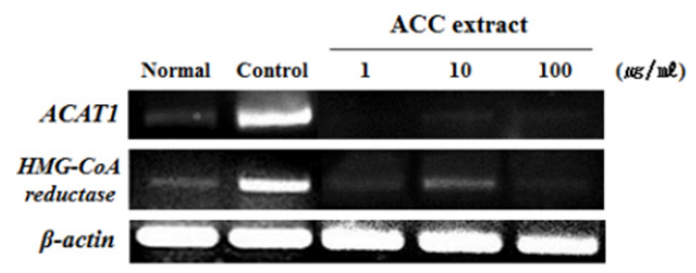

Fig. 7. Effect of ACA extract on ACAT1 and HMG-COA reductase mRNA expression in HepG2 cells.

\section{IV. 고 찰}

심혈관계 질환은 전체 사망 원인의 $30 \%$ 정도로 가장 중요한 사망 원인이다. 최근 심혈관계 질환의 유발요인 중 흡연율은 감소하고 있으며 고혈압과 당뇨병의 유병률은 비교적 일정하게 유지되고 있 는 반면에 이상지질혈증의 유병률은 증가하는 추 세로 $^{13}$ 이에 대한 관심 및 치료제 개발 연구가 늘 어나고 있는 추세이다.

이상지질혈증이란 triglycerides(TG), HDL-cholesterol, LDL-cholesterol, 총 cholesterol 중 한 개 이상이 정상 범위를 벗어나는 것을 말한다. 이상지질혈증은 죽상 동맥경화증의 큰 위험인자로 혈중 LDL-cholesterol은 혈관의 내피세포의 기질과 쉽게 결합하여 혈관 내 막에 침윤된다. 침윤된 $\mathrm{LDL}$-cholesterol이나 혈액 의 염증인자들은 내피세포의 기능부전을 일으키고 내피세포를 활성화 시켜 염증 유전자나 부착분자 의 발현을 증가시킨다. 산화 $\mathrm{LDL}$ 은 단핵구, 대식 세포, $\mathrm{T}$ 세포 등을 활성화시키며 만성적인 염증 상 태를 유발하여 혈관 내막으로 이주한 혈관평활근 세포가 산화 변형된 지단백을 섭취하여 섬유판을 형성한다. 따라서 죽상동맥경화의 가장 중요한 위
험인자는 혈중 cholesterol의 상승이며 이상지질혈 증의 치료는 관상동맥질환의 발병률을 낮추는 것 으로 밝혀졌다 ${ }^{14}$.

이상지질혈증에 대한 치료는 체중감량이나 식사 요법, 운동요법을 실시하며 생활요법 개선 후에도 조절이 잘 되지 않으면 약물요법을 병행한다. 약물요법 은 Bile-acid sequestrants, Nicotinic acid, HMG-CoA reductase inhibitors, Fibrates가 있는데, $\mathrm{HMG}-\mathrm{CoA}$ reductase inhibitor인 스타틴이 일차 선택약제이다. 비교적 부작용이 적고 LDL-cholesterol을 낮출 수 있기 때문이다. 그러나 가장 흔하게 소화장애, 속 쓰림, 복통 등이 나타나며 간 독성과 근육 독성이 나타날 수 있다2.

이상지질혈증이란 병명은 한의학에서 직접적으 로 언급된 바는 없지만 《靈樞 - 五痕津液別篇》에 서는 “五穀之津液, 和合而爲高者, 內滲入於骨空, 補 益腦髓라 하며 稁는 곧 脂質으로 볼 수 있고 津液 의 一種으로써 水穀에서 來源하여 血中에 化入하 고 人體의 營養物質이 된다 ${ }^{15}$ 라고 서술하고 있다. 이상지질혈증은 疙血이나 痰飲으로 유발된 질환으 로 볼 수 있으며 利濕化痰, 活血化疙의 治法을 쓸 수 있다 ${ }^{16}$. 그와 관련하여 단일 약재 ${ }^{3-5}$ 와 복합제 ${ }^{67.9-11}$, 약침을 이용한 연구 ${ }^{8}$ 등 다양한 치료제 개발이 활 발히 이루어지고 있다.

본 연구에 활용된 茵蔯은 본초학의 분류에서 利 水滲濕藥에 속하며 清濕熱, 退黃疸의 효능이 있다 ${ }^{17}$. 鬱金은 본초학상 活血祛疙藥에 속하며 活血止痛, 行氣解鐢, 清心凉血, 疏肝利膽하는 효능이 있다 ${ }^{17}$. 鬱金은 항산화와 항고지혈증에 대하여 유효한 효 과를 보이고 있다 ${ }^{18.19}$. 枳實은 본초학상 理氣藥에 속하며 破氣消積, 化痰散㾂하는 효능을 가지고 있 는데 항고지혈증 및 항염증효능에 유효한 효과를 보인다는 연구가 있다.

항고지혈과 관련한 연구들에서는 항산화 효능과 관련된 연구를 함께 진행하는 경우가 많다. 이는 이상지질혈증 초기에 활성산소와 산화적 스트레스 가 체내 과잉되어 동맥경화를 비롯하여 암이나 노 
화를 유발 가능하기 때문이다. 따라서 항산화제는 산화적 스트레스를 억제하여 이상지질혈증에 의한 여러 혈관장애 유발인자를 억제하고 질병 예방 목 적으로 활용될 수 있다 ${ }^{20}$

본 연구에서는 항산화 효능을 평가하기 위하여 $\mathrm{DPPH}$ radical 소거능, ABTS radical 소거능을 측 정했고 세포 내 ROS의 생성량, glutathione의 함량 을 측정했으며 이상지질혈증의 개선 효능 평가를 위하여 세포 내 free fatty acid 함량과 세포 내 lipid peroxidation을 측정했다. 그리고 지질의 전구체인 ACAT1과 cholesterol을 free cholesterol로 생합성하 는 효소인 $\mathrm{HMG}-\mathrm{CoA}$ reductase 발현 수준을 측정 하였다.

$\mathrm{HepG2}$ 세포는 사람의 주요 apo단백질을 합성하 는 능력을 갖고 있어 lipoprotein의 대사에 관련한 연구에 사용되어지기에 적절하며 증식률이 빠르기 때문에 본 실험에서는 HepG2 세포를 이용하여 진 행하였다 ${ }^{21}$.

연구에 앞서 복합추출물 $\mathrm{ACA}$ 의 안전성 검증을 위하여 중금속 함량을 관찰한 결과 납, 카드뮴의 경우 기준치 이하로 검출되었고 비소와 수은의 경 우는 검출되지 않았다(Table 2). DPPH radical 소 거능, ABTS radical 소거능 측정이란 항산화능 측 정에 널리 사용되는 방법으로 항산화 특성이 클수 록 소거능이 증가하는 특징을 가진다 ${ }^{22}$. 복합추출물 $\mathrm{ACA}$ 를 $1,10,100,1,000(\mu \mathrm{g} / \mathrm{ml})$ 농도로 희석시킨 후 DPPH radical 소거능과 ABTS radical 소거능 을 측정하였는데 측정한 $\mathrm{DPPH}$ radical소거능과 ABTS radical 소거능은 농도 의존적으로 증가가 나타났다(Fig. 1, 2). 이 결과로 볼 때 복합추출물 $\mathrm{ACA}$ 가 항산화 활성을 나타내는 것으로 사료된다.

활성산소(ROS)는 산소의 산화물이며 항산화물 질인 glutathione $(\mathrm{GSH})$ 은 직접 활성산소와 결합하 여 제거한다 ${ }^{23}$. HepG2 세포에 복합추출물 $\mathrm{ACA}$ 를 처리한 후 측정된 ROS의 양은 모든 농도에서 유 의한(p<0.001) 감소를 보였다(Fig. 3). HepG2 세포에 복합추출물 $\mathrm{ACA}$ 를 처리한 후 측정한 세포 내 GSH
함량은 모든 농도에서 유의성 있는 증가를 나타냈다 (Fig. 4). 따라서 복합추출물 ACA는 glutathione을 합성, 촉진 효능을 나타내며 그와 관련된 항산화효 소 활성 촉진 효능도 월등한 것을 볼 수 있다.

세포 내에서 이상지질혈증 개선 효능을 평가하기 위하여 $\mathrm{HepG2}$ 세포에 복합추출물 $\mathrm{ACA}$ 를 처리한 후 세포 내 free fatty acid 함량과 lipid peroxidation 을 측정했다. Free fatty acid는 지방조직에서 방출되 어 혈액 내에 존재하는 지질이고 lipid peroxidation 은 불포화지방산이 과산화한 것으로 반응성이 커서 생체막계에 상해를 주고, 세포의 기능저하나 괴사를 야기할 수 있다 ${ }^{24}$. 본 연구에서는 lipid peroxidation 을 측정하기 위하여 $\mathrm{MDA}$ 농도를 측정하는 법을 사용했다. 세포 내 free fatty acid 함량은 모든 농 도에서 유의한 감소를 보였으며(Fig. 5), 세포 내 lipid peroxidation(MDA)도 모든 농도에서 유의한 감소를 나타내어(Fig. 6) 복합추출물 $\mathrm{ACA}$ 가 혈중 의 지질 과산화를 억제하고, 아울러 혈중 콜레스테 롤 함량 및 지질함량을 감소시키는 영향을 미칠 수 있다는 것을 밝힐 수 있다.

$\mathrm{ACAT}$ 는 식이로 섭취한 cholesterol을 세포내로 저장하는 효소이며 ${ }^{25} \mathrm{HMG}-\mathrm{CoA}$ reductase는 간에 서 $\mathrm{LDL}$ 수용체에 의해 유입된 cholesterol을 free cholesterol로 생합성하는 효소이기 ${ }^{26}$ 때문에 $\mathrm{ACAT}$ 와 $\mathrm{HMG}^{-\mathrm{CoA}}$ 효소의 저해는 혈중 cholesterol을 감소시킬 수 있다. HepG2 세포에 복합추출물 $\mathrm{ACA}$ 를 처리한 후 $\mathrm{ACAT1}$ 와 $\mathrm{HMG}-\mathrm{CoA}$ reductase $\mathrm{mRNA}$ 발현은 모든 농도에서 발현량이 확연히 감소된 것 을 확인되었다(Fig. 7). 이를 통해 복합추출물 $\mathrm{ACA}$ 는 세포내 콜레스테롤의 축적과 생합성을 감소시 킬 수 있다고 볼 수 있다.

이상의 결과들을 종합해 보면, 복합추출물 $\mathrm{ACA}$ 는 중금속이 검출되지 않았으며 실험 내의 농도에 서 세포독성을 나타내지 않았다. DPPH radical과 ABTS radical 소거능의 증가, ROS 생성량 감소, $\mathrm{GSH}$ 를 촉진하는 결과를 나타내어 항산화 효과를 증명했다. 그리고 세포 내 free fatty acid, lipid 
茵蔯, 棍金, 枳實 추출물(ACA)이 HepG2 세포에서 나타나는 이상지질혈증 관련 인자 발현 및 항산화에 미치는 영향

peroxidation의 감소, cholesterol 관련 효소 발현을 억제하여 세포내 cholesterol의 축적과 생합성을 감 소시킬 수 있음을 입증했다.

다만, 본 실험이 세포 연구 수준에서 이루어져 혈중 LDL-cholesterol이나 total cholesterol, TG의 측정이 이루어지지 않아 이상지질혈증의 개선 효 능을 명확히 결론짓기는 어렵다. 따라서 추후 in vivo 실험을 통해 효과를 입증할 필요가 있다. 그 러나 본 연구를 통하여 복합추출물 $\mathrm{ACA}$ 는 혈관의 산화적 손상을 예방하고 억제할 수 있을 것으로 보여지며 더 나아가 이상지질혈증을 개선해 줄 수 있는 가능성을 확인할 수 있었다. 향후 복합추출물 $\mathrm{ACA}$ 에 대한 지속적인 연구가 이루어지기를 기대 한다.

\section{V. 결 론}

茵蔯, 鬱金, 枳實의 복합 추출물은 이상지질혈증 관련 인자 발현을 억제시키며 항산화 효능이 있다 고 보여진다. 추후 in vivo 실험을 통해서 항고지혈 효능을 입증하는 과정이 추가적으로 필요하지만 복합추출물 $\mathrm{ACA}$ 는 이상지질혈증 개선 가능성이 있을 것으로 보여진다. 이를 이용한 심도 있고 다 양한 연구가 필요할 것으로 사료된다.

\section{참고문헌}

1. World Health Organization(CH). Global Health Observatory(GHO) data. Deaths from NCDs [Internet]. Geneva: World Health Organization; 2012 [cited 2015 May 19].

2. Committee for Guidelines for Management of Dyslipidemia. 2015 Korean Guidelines for Management of Dyslipidemia. J Lipid Atheroscler 2015;4(1):61-92.

3. Jang US. Lipid-lowering and Antioxidant Effect of Artemisia capillaris in Poloxamer-407 induced Hyperlipidemia Model in Rat. Doctor's thesis in Daejeon university 2011.

4. Park SA, Jo HK, Yoo HR, Kim YS, Seol IC, An JJ. Lipid-lowering and Antioxidant Effect of Curcuma Radix in Poloxamer 407-induced Hyperlipidemia Model in Rat. The $J$ of Korean Oriental Internal Medicine 2011;32(2):243-58..

5. Ham IH, Lee UC, Lee BH, Choi HY. Lipid lowering activity of Ponciri Fructus and Aurantii Fructus Immaturus on hyperlipemia rats induced by Triton WR-1339. $J$ of Herbology 2007;22(3): 109-16.

6. Kim YD. A study of the effects of Gualouzhishitang and Gualouzhishitangjiawei on hyperlipidemia. Master's thesis in Dongguk University 1993.

7. An GY, Jo JJ, Shin MG, Jeon SY. Study of the effects of gugijagami-bang in a hyperlipidemic animal model induced with a high-fat diet. The $J$ of Korean Oriental Internal Medicine 2014; 35(4):505-18.

8. Park CY, Hong GU. A Study on the Effect of Herbal-acupuncture with HK-1000 Solution on Hyperlipidemia and Arteriosclerosis Induced Rats. $J$ of Pharmacopuncture 2008:11(3):55-66.

9. Lee SJ, Han JM, Lee JS, Son CG, Im HJ, Jo HK, et al. ACE Reduces Metabolic Abnormalities in a High-Fat Diet Mouse Model. Evid Based Complement Alternat Med 2015:2015:1-8.

10. Kim HT, Kim YS, Seol IC, Yoo HR. The Effects of an Extract of Artemisiae Capillaris, Curcumae Longae, and Crataegi Fructus(IUS) on Antihyperlipidemia and Anti-oxidation in $\mathrm{db} / \mathrm{db}$ Mouse Model. The $J$ of Internal Korean Medicine 2016:37(3) :467-83.

11. Choi KE, Seol IC, Kim YS, Cho HK, Yoo HR. Hypolipidemic and Anti-oxidant Effects 
of Chunghyl Plus in Type II Diabetic Mice Model. $J$ of Physiology \& Pathology in Korean Medicine 2016:30(3) :164-76.

12. Kim BM, Jung JH, Kim DS, Kim YM, Jeong IH. Inhibitory activity of intracellular lipid accumulation by various marine extracts in HepG2 cells. Korean J Food Sci Technol 2012; $44: 362-6$.

13. Ministry of Health and Welfare, Korea Centers for Disease Control and Prevention, Korea Health Statistics 2015: Korea National Health and Nutrition Examination Survey, 3rd Year of the Sixth Period(2015). Cheongju: Korea Centers for Disease Control and Prevention; 2016, p. 24, 50-5.

14. Kim JC. SIM Integral medicine. Part III; Cardiology. Seoul: Jungdam; 2013, p. 205-8.

15. Yang YG. Interpretation of Huang Di Nei Jing(Yellow Emperor's Inner Canon) Yeongchu. Seoul: Iljungsa; 1991, p. 296-7.

16. Bang HJ, Tak US, Hong Y, Kang YH. Korean medicine approach to hyperlipidemia. $J$ of East-west Medicines 1995;20(1):25-36.

17. Association Textbook Publish Committee of National Oriental Medical Department. Herbal medicine. Seoul: Younglimsa; 2010, p. 369-70, 392-3, 452-3.

18. Kim MS, Chun SS, Choi JH. Effects of Turmeric (Curcuma longa L.) on Antioxidative Systems and Oxidative Damage in Rats Fed a High Fat and Cholesterol Diet. $J$ Korean Soc Food Sci Nutr 2013;42:570-6.

19. Shon MS, Kim GN. Anti-oxidant and Anti- obese Activities of Turmeric (Curcuma longa L.) Extract in 3T3-L1 Cells. Kor $J$ Aesthet Cosmetol 2014;12(2) :169-75.

20. Yang RL, Shi YH, Hao G, Li W, Le GW. Increasing Oxidative Stress with Progressive Hyperlipidemia in Human: Relation between Malondialdehyde and Atherogenic Index. $J$ of clinical biochemistry and nutrition 2008;43(3): 154.

21. Wang SR, Pessah M, Infante J, Catala D, Salvat C, Infante R. Lipied and lipoprotein metabolism in Hep G2 cells. Biochi Biophy Acat 1988; 961:351-63.

22. Kim MJ, Park EJ. Feature Analysis of Different In Vitro Antioxidant Capacity Assays and Their Application to Fruit and Vegetable Samples. $J$ Korean Soc Food Sci Nutr 2011;40(7) :1053-62.

23. Meister A, Anderson ME. Glutathione. Annu Rev Biochem 1983:52:711-60.

24. Kim DH. The Relation of Aging, Chronic Degenerative Disease, and Lipid Peroxides. $J$ of Exercise Nutrition \& Biochemistry 2000;4(2): 63-71.

25. Vaziri ND, Liang K. Up-regulation of acylcoenzyme A:cholesterol acyltransferase(ACAT) in nephrotic syndrome. Kidney Int 2002;61(5): 1769-75.

26. Liang $\mathrm{K}$, Kim $\mathrm{CH}$, Vaziri ND. $\mathrm{HMG}^{-\mathrm{Co}} \mathrm{A}$ reductase inhibition reverses LCAT and LDL receptor deficiencies and improves HDL in rats with chronic renal failure. Am $J$ Physiol Renal Physiol 2005;288(3):539-44. 